\title{
31. DATA REPORT: MECHANICAL BEHAVIOR OF BASALT FROM COSTA RICA RIFT, HOLE 504B, LEG $137^{1}$
}

\author{
Basiles Christaras ${ }^{2}$
}

\begin{abstract}
Core samples of basalt collected from Hole 504B during Leg 137 were investigated regarding their mechanical behavior. The rock samples were measured for hardness, compression strength, and modulus of elasticity. Abrasion loss of weight and Shore sclerometer methods were used for determining hardness. Static and dynamic methods were used for calculating modulus of elasticity. Test results were compared with shipboard measurements of ultrasonic velocity and dry-bulk density. Test results were interpreted statistically to provide data not only on mechanical behavior changes of the rock but also on the precision of the methods used.
\end{abstract}

\section{INTRODUCTION}

Hole 504B is located in the southern part of the Costa Rica Rift (between the Ecuador and Panama fracture zones) in the eastern equatorial Pacific Ocean (Fig. 1). The primary purpose of Leg 137 (20 March-1 May 1991) was to clean out Hole 504B in preparation for subsequent deepening through the basalt and sheeted dikes. Once it was verified that the hole was cleaned of all remnants of junk, coring operations continued for about $50.50 \mathrm{~m}$.

Core material collected during Leg 137 was investigated to provide data for the mechanical behavior of the rock in order to complete its characterization at the corresponding coring depths. Test results were interpreted statistically using correlation methods and diagrams to determine relationships between the above properties.

\section{GEOLOGICAL SETTING}

Hole 504B is located in 5.9-m.y.-old crust in the southern part of Costa Rica Rift and extends through $274.5 \mathrm{~m}$ of sediment and 1347 $\mathrm{m}$ of basement, a total penetration of $1621.5 \mathrm{~m}$. The $1347 \mathrm{~m}$ of basement cored consists of $571.5 \mathrm{~m}$ of pillow lavas and minor flows, underlain by a $209-\mathrm{m}$ zone of transition into $566.5 \mathrm{~m}$ of sheeted dikes and massive units. Basement rocks recovered are fine- to mediumgrained, plagioclase-olivine-clinopyroxene-chromite spinel, phyric basalt, with aphyric types more abundant with depth. All recovered basalts are mineralogically and chemically altered to some extent (Alt et al., 1986; Morin et al., 1989; Shipboard Scientific Party, 1992).

\section{METHODOLOGY}

Rock samples were measured for their hardness, compressive strength, and modulus of elasticity. Shipboard measurements of dry compressional- $(P)$ and shear- $(S)$ wave velocities as well as dry-bulk density (Shipboard Scientific Party, 1992) were also used for the interpretation of test results (Tables 1 and 2).

Tests were applied on the same minicores of $24.67-\mathrm{mm}$ diameter and \pm 20 -mm height that were already used for ultrasonic velocity and dry-bulk density determination; abrasion loss of weight measurements were conducted on specimens of 10 -mm height. Specimens were prepared with the use of the shipboard SBA minicore drilling machine. Minicores without visible fractures were collected carefully, to be representative of the core or section lithology. The minicores were cut with

\footnotetext{
'Erzinger, J., Becker, K., Dick, H.J.B., and Stokking, L.B. (Eds.), 1995. Proc. ODP, Sci. Results, 137/140: College Station, TX (Ocean Drilling Program).

${ }^{2}$ Laboratory of Engineering Geology and Hydrogeology, School of Geology, Aristotle University, 54006 Thessaloniki, Greece.
}

the axis perpendicular to the splitting surface. The surfaces of the minicores were shaped to ensure flat ends. The length-to-width ratio of specimens generally required for mechanical tests is from $2: 1$ to $2.5: 1$ (Jaeger and Cook, 1979), but the quantity and dimensions of coring material obliged us to use specimens with the above dimensions.

Hardness was measured as rebound of a falling hammer, using a Shore sclerometer, and as abrasion loss of weight, using a thin-section lapping machine. Young's modulus (modulus of elasticity) was measured using both static and dynamic methods.

\section{Hardness}

Hardness expresses the ability of rocks to resist tracing and abrasion. Concerning the quantitative determination of this property, several indirect methods have been proposed in the past because no direct determination is possible. The methods used in the present investigation are referred to as the rebound of a falling diamond hammer (Shore scleroscope method [Tsoutrelis, 1968]) and the recently proposed abrasion loss of weight (Christaras, in press).

\section{Shore Scleroscope Method}

This method measures the rebound of a pointed diamond hammer falling from a fixed height and making a minute indentation in the specimen, using a Shore Scleroscope Model C2 of Shore Instrument \& MFG. Company Inc. The hammer rebounds, but not to its original height, because some of the energy in the falling hammer is dissipated in producing an indentation. The rebound of the hammer varies in proportion to the hardness of the specimen (the higher the rebound, the harder the tested material). The scale consists of units that are determined by dividing the average rebound of the hammer from quenched tool steel of ultimate hardness into 100 equal parts $(\mathrm{H}$, in Shore degrees). These rebounds will run from 95 to 105 . The scale is carried higher than 100 to cover super-hard materials. Test results are the mean values of 200 measurements for each specimen, ensuring the accuracy of the results and the repeatability of the method.

\section{Abrasion Loss of Weight}

Hardness of rocks can also be expressed by the "abrasion loss of weight" (AR, percentage). The method used is based on the calculation of the loss of weight of a pre-weighted sample after abrasion for a constant time under constant conditions. For this purpose a LOGITECH-LP 30 thin-section lapping machine with constant rotation of $40 \mathrm{rpm}$ is used. Tests are applied on minicores of $24.67-\mathrm{mm}$ diameter and $10-\mathrm{mm}$ height, rather than $20 \mathrm{~mm}$, which was the ordinary height used for the other tests, ensuring no damage of the edges. The 


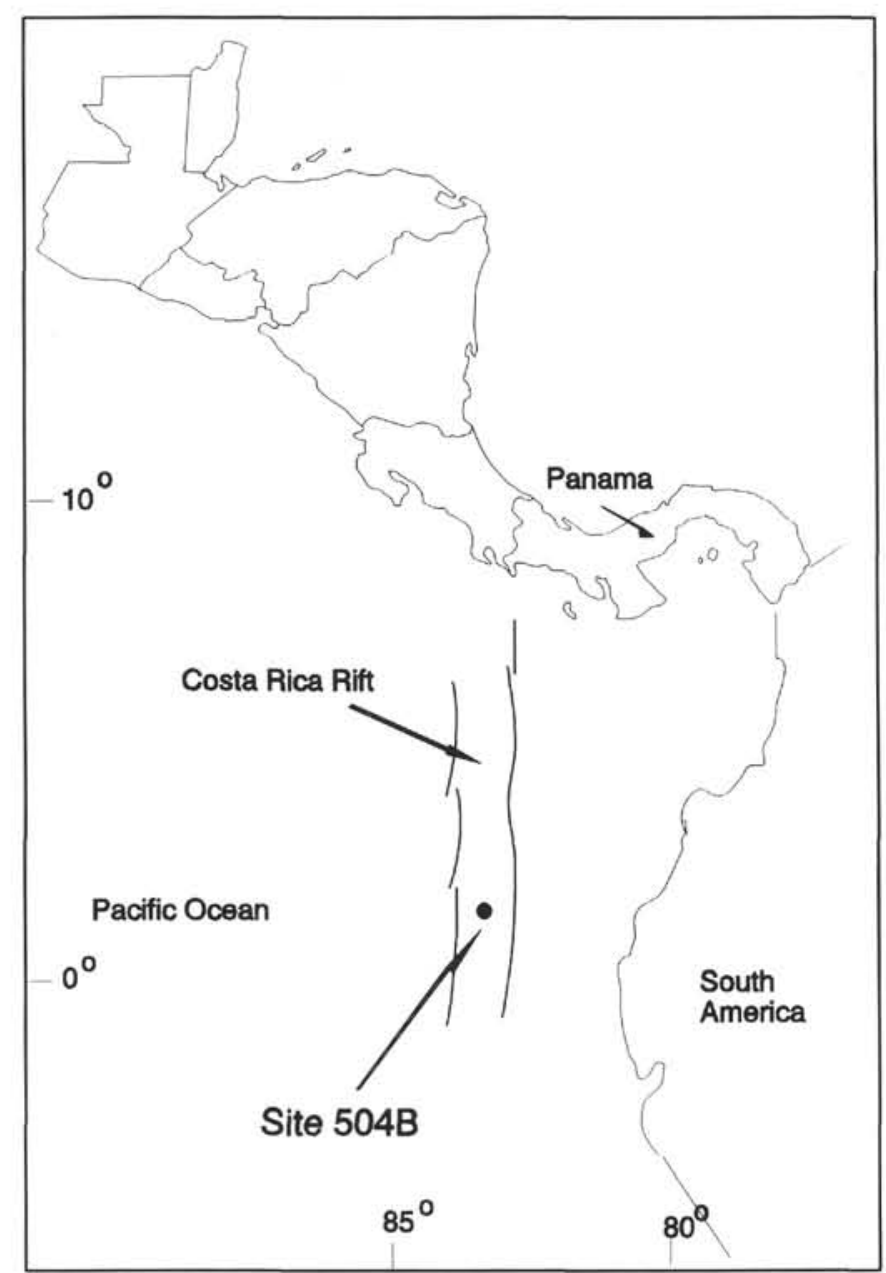

Figure 1. Location of Hole 504B.

Table 1. Hardness using abrasion loss of weight (AR) and Shore (H) methods, as well as dry $\boldsymbol{P}$ - and $S$-wave velocities measured in basalts from Hole 504B.

\begin{tabular}{lccccc}
\hline $\begin{array}{c}\text { Core, section, } \\
\text { interval }(\mathrm{cm})\end{array}$ & $\begin{array}{c}\text { Depth } \\
(\mathrm{mbsf})\end{array}$ & $\begin{array}{c}\text { AR } \\
(\%)\end{array}$ & $\begin{array}{c}\mathrm{H} \text { (Shore } \\
\text { degrees) }\end{array}$ & $\begin{array}{c}d v p \\
(\mathrm{~mm} / \mu \mathrm{s})\end{array}$ & $\begin{array}{c}d v s \\
(\mathrm{~mm} / \mu \mathrm{s})\end{array}$ \\
\hline 137- & & & & & \\
173R-1, 6-8 & 1570.06 & 1.57 & 62.03 & 5.651 & 3.534 \\
173R-1, 105-108 & 1571.05 & 1.55 & 62.02 & 5.758 & 3.628 \\
174R-1, 53-56 & 1576.83 & 1.55 & 62.40 & 5.822 & 3.622 \\
174R-2,96-99 & 1578.73 & 1.35 & 62.08 & 5.856 & 3.718 \\
175R-1,13-16 & 1585.93 & 1.38 & 62.66 & 5.867 & 3.700 \\
176R-1,106-112 & 1596.36 & 1.19 & 65.16 & 5.828 & 3.714 \\
178R-1, 20-24 & 1614.00 & 1.40 & 62.73 & 5.726 & 3.578 \\
180M-1, 78-82 & 1618.13 & 1.48 & 61.30 & 5.528 & 3.551 \\
180M-2, 67-78 & 1619.03 & 1.56 & 61.63 & 5.700 & 3.644 \\
181M-1,26-29 & 1619.37 & 1.58 & 60.71 & 5.608 & 3.436 \\
181M-1, 147-150 & 1621.50 & 1.69 & 56.88 & 5.609 & 3.502 \\
\hline
\end{tabular}

Note: $d v p=P$-wave velocity, $d v s=S$-wave velocity.

polishing material (sand) is emery of grain size no. 400 , and the specimens are loaded with $2 \mathrm{~kg}$. The abrasion time is $1 / 2 \mathrm{hr}$.

Test results are accurate and repeatable not only for fine-grained rocks, like the studied basalt, but also for medium- and cross-grained rocks without very big phaenocrystals (e.g. trachyte etc.). Our previous studies in limestones and sandstones (Christaras, 1991a) as well as in ophiolites (in both gabbros and peridotites [Christaras, in press]) provided significant correlations between abrasion loss of weight and the other common physico-mechanical properties.
Table 2. Dry-bulk density, uniaxial compressive strength, and static and dynamic Young's moduli of basalts from Hole 504B.

\begin{tabular}{lccccc}
\hline $\begin{array}{c}\text { Core, section, } \\
\text { interval }(\mathrm{cm})\end{array}$ & $\begin{array}{c}\text { Depth } \\
(\mathrm{mbsf})\end{array}$ & $\begin{array}{c}\text { DBD } \\
\left(\mathrm{g} / \mathrm{cm}^{3}\right)\end{array}$ & $\begin{array}{c}\text { UCS } \\
(\mathrm{MPa})\end{array}$ & $\begin{array}{c}E_{s} \\
(\mathrm{GPa})\end{array}$ & $\begin{array}{c}E_{d} \\
(\mathrm{GPa})\end{array}$ \\
\hline 137- & & & & & \\
173R-1,6-8 & 1570.06 & 2.94 & 148.5 & 76.37 & 86.57 \\
173R-1, 105-108 & 1571.05 & 2.96 & 209.2 & 88.66 & 91.23 \\
174R-1, 53-56 & 1576.83 & 2.96 & 188.3 & 83.75 & 91.98 \\
174R-2,96-99 & 1578.73 & 2.97 & 219.6 & 96.18 & 95.44 \\
175R-1, 13-16 & 1585.93 & 2.98 & 217.6 & 92.43 & 95.45 \\
176R-1, 106-112 & 1596.36 & 2.98 & 198.7 & 90.33 & 95.21 \\
178R-1, 20-24 & 1614.00 & 2.94 & 177.6 & 89.02 & 88.80 \\
180M-1, 72-82 & 1618.13 & 2.95 & 154.8 & 77.44 & 85.46 \\
180M-2, 67-78 & 1619.03 & 2.94 & 167.4 & 74.66 & 90.13 \\
181M-1, 26-29 & 1619.37 & 2.95 & 154.8 & 82.04 & 83.55 \\
181M-2, 147-150 & 1621.50 & 2.92 & 150.6 & 81.10 & 84.55 \\
\hline
\end{tabular}

Note: $\mathrm{DBD}=$ dry-bulk density, UCS = uniaxial compressive strenth, $E_{s}$ and $E_{d}$ = static and dynamic Young's moduli.

\section{Compressive Strength}

Compressive strength (UCS, MPa) was measured according to ASTM C 97-47 specifications by dividing the compressive force by the surface of the base of the cylindric specimen. For this purpose a 100/450-KN Weber PW 40E compression machine was used, calibrated according to the instructions of the factory. The machine was equipped with an electro-hydraulic directly connected motor-driven pump, a solenoid valve, and a pressure valve. A low-pressure contact pressure gauge, inductively operated as desired (indication range $25 \%$ of main contact pressure gauge: $100 \mathrm{KN}$ ), with automatic closing and shut-off valve.

\section{Young's Modulus of Elasticity}

The most commonly determined elastic constant that characterizes the elastic deformation responses of a material to applied stress is Young's modulus, or the modulus of elasticity. This can be determined either statically, using compression methods, or dynamically, using ultrasonic velocity techniques.

\section{Static Modulus of Elasticity}

Deformation data for specimens undergoing strength tests may be obtained and used to calculate the static elastic moduli of intact rock. The static modulus of elasticity, which is derived from a form of Hooke's law, is calculated from applied axial compressive stresses and resulting axial strains $\left(E_{s}=\sigma_{n} / \varepsilon\right.$, where $E$ : Young's modulus, in $\mathrm{Pa}$ or $\mathrm{GPa} ; \sigma_{n}$ : normal stress; and $\varepsilon$ : axial strain). Rate of stress application will result in different $\mathrm{E}$ values for the same material.

Young's modulus is useful in estimating the elastic response of intact rock to compression from in-situ construction and post-construction stresses. Abutment stresses in a dam or those exerted against the rock by water-pressure tunnels are examples of post-construction stresses.

The values for $E$-modulus may be obtained from stress-strain diagrams. Of the average modulus, tangent modulus, and secant modulus referred to in the literature, the last one is most commonly used, as it predicts the maximum elastic deformation that would occur at $50 \%$ of the ultimate strength (Johnson and De Graff, 1988).

In the present investigation, Young's modulus was measured using the secant modulus method. Unfortunately, the small size of the specimens did not permit us the use of high-precision deformation gauges. Thus, deformation was measured using a KYOWA micrometer connected to an amplifier. The precision of the instrument was $0.01 \mathrm{~mm}$; a third digit of precision is given by the amplifier, so an approximate evaluation to the third digit is possible. The accuracy of these test results is not high, but the significant correlation between static and dynamic moduli of elasticity defends the use of these results. 


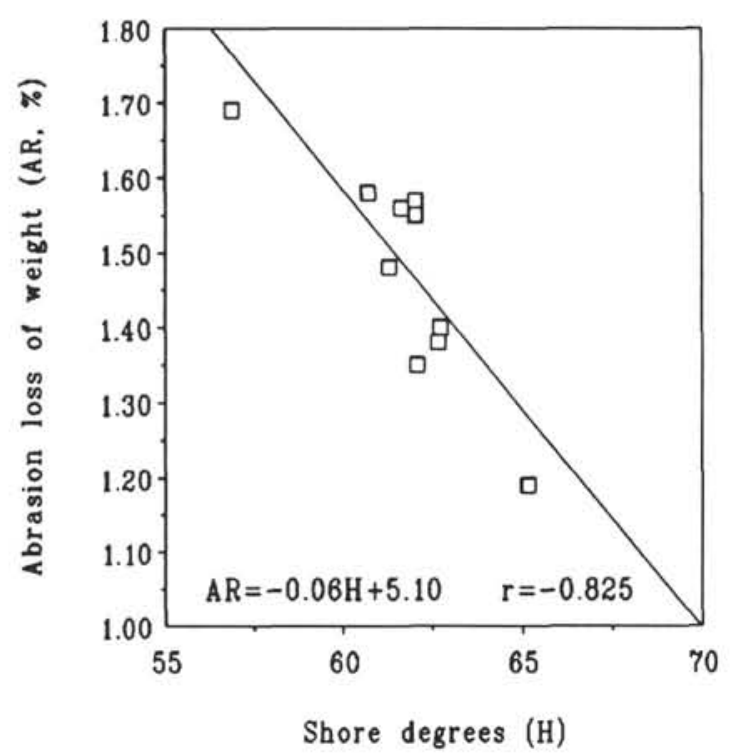

Figure 2. Correlation diagram between abrasion loss of weight (AR) and Shore hardness $(\mathrm{H})$ of basalts from Hole 504B, Leg 137.

\section{Dynamic Modulus of Elasticity}

Modulus of elasticity may be obtained by dynamic methods, in addition to static compression tests. One common dynamic method for elastic moduli determination is to subject the rock sample to compression and shear-wave pulse. Compression and shear-wave transducers are attached to the ends of the core specimen for this purpose. Wave velocity is calculated from the traveltime of the pulse through the specimen. Samples may be loaded to approximately field conditions because both $P$ - and $S$-wave responses increase with compression. Typically the dynamic modulus of elasticity is greater than the static one, because the response of the specimen to the very short duration strain and low stress level is essentially purely elastic (Clark, 1966).

In the present investigation, dynamic Young's modulus $\left(E_{d}\right.$, in $\mathrm{GPa}$ or $\mathrm{Pa}$ ) was determined using the dry ultrasonic velocity ( $d v p$, $d v s)$ test results, obtained during Leg 137, according to the following equation:

$$
E_{d}=\mathrm{DBD} * \frac{d v s^{2}\left(3 d v p^{2}-4 d v s^{2}\right)}{d v p^{2}-d v s^{2}}
$$

where:

$E_{d}=$ Young's modulus $(\mathrm{Pa})$,

$\mathrm{DBD}=$ Dry-bulk density $\left(\mathrm{Kg} / \mathrm{m}^{3}\right)$,

$d v p=P$-waves velocity $(\mathrm{m} / \mathrm{s})$, and

$d v s=S$-waves velocity $(\mathrm{m} / \mathrm{s})$.

\section{EXPERIMENTAL RESULTS}

Mechanical properties investigation can provide data that complete the description and classification of a rock. Coring rate during drilling operations is related directly to the compression strength and hardness, whereas ultrasonic velocity could be related to the rock fabric, deformation, and weathering condition of rock (Dearman, 1976; Christaras, 1991b).

In our investigation, only 11 representative basalt samples were studied because coring activities were performed in a limited depth range, between 1570.0 and $1621.5 \mathrm{mbsf}$. Test results were interpreted statistically concerning the relationship observed between the studied methods. These relationships were expressed mathematically and by regression diagrams.

The correlations were verified for their significance at the level of $99 \%$ and $98 \%$ for $n-2=9$, by calculation of the following equation

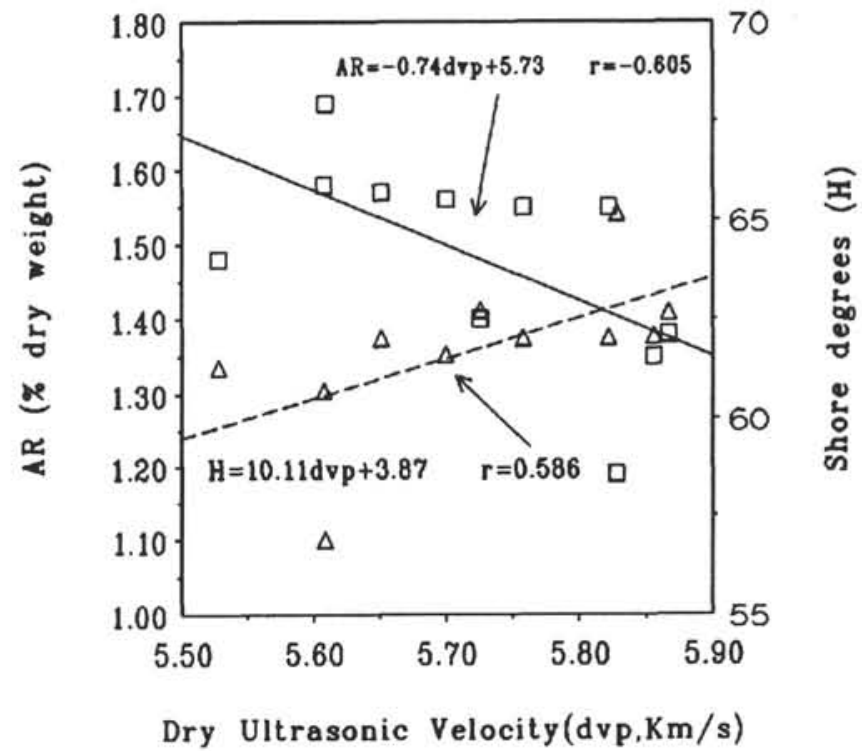

Figure 3. Correlation diagram between dry compressional ultrasonic velocity $(d v p)$ and hardness $(\mathrm{AR}, \mathrm{H})$ of basalts from Hole 504B, Leg 137. Squares = $\mathrm{AR}$; triangles $=\mathrm{H}$.

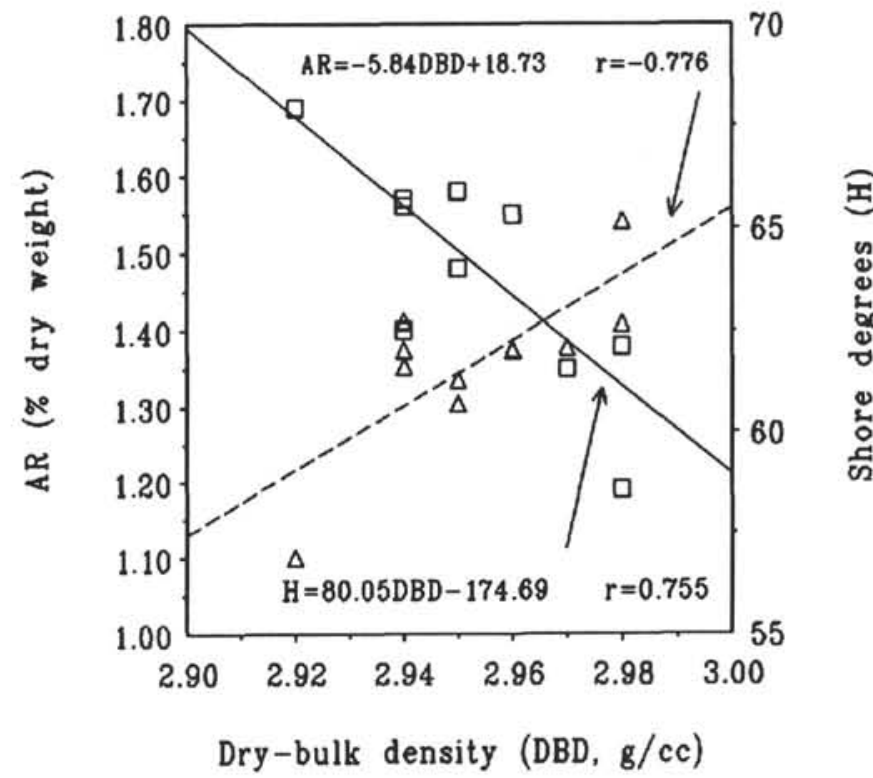

Figure 4. Correlation diagram between dry-bulk density (DBD) and hardness (AR, H) of basalts from Hole 504B, Leg 137. Squares $=\mathrm{AR}$; triangles $=\mathrm{H}$.

using the Students Tables ( $t$ : Student value, $r$ : correlation coefficient, $n$ : number of samples):

$$
t=\frac{r \sqrt{n-2}}{\sqrt{1-r^{2}}}
$$

According to our test results, high-level significance correlations (level $99 \%$ or $98 \%$ ) between the studied properties were observed.

Hardness was measured as abrasion loss of weight, in addition to the commonly used Shore method, and test results were compared (Fig. 2). The significant relationship observed between the two methods confirms the precision of the abrasion method.

Hardness is also related to the ultrasonic velocity and dry-bulk density (Figs. 3 and 4), confirming the relationship of hardness with 


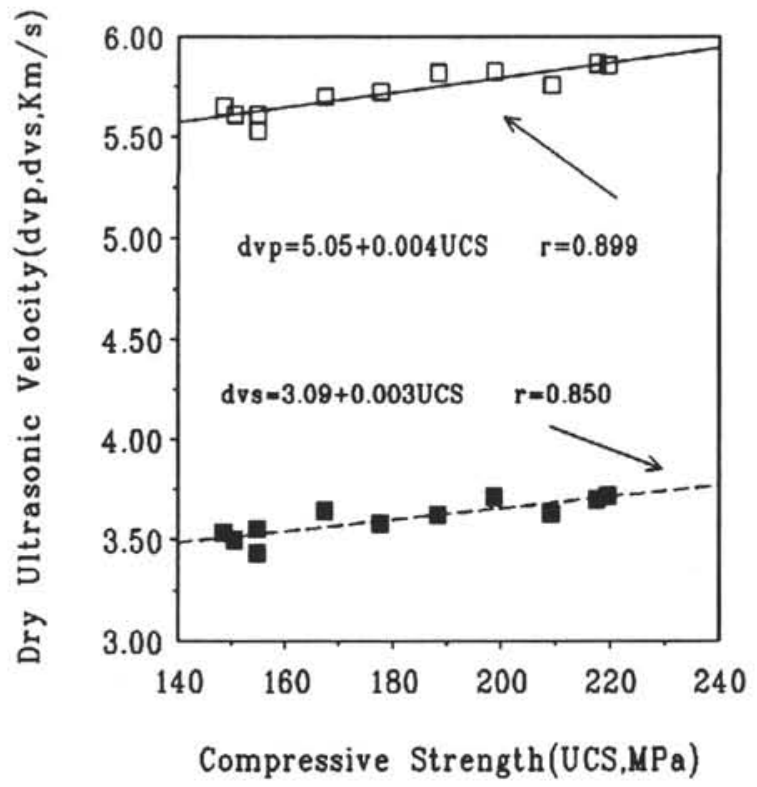

Figure 5. Correlation diagram between uniaxial compressive strength (UCS) and dry $P / S$-wave velocities ( $d v p, d v s)$ of basalts from Hole 504B, Leg 137. Open squares $=d v p$, filled squares $=d v s$.

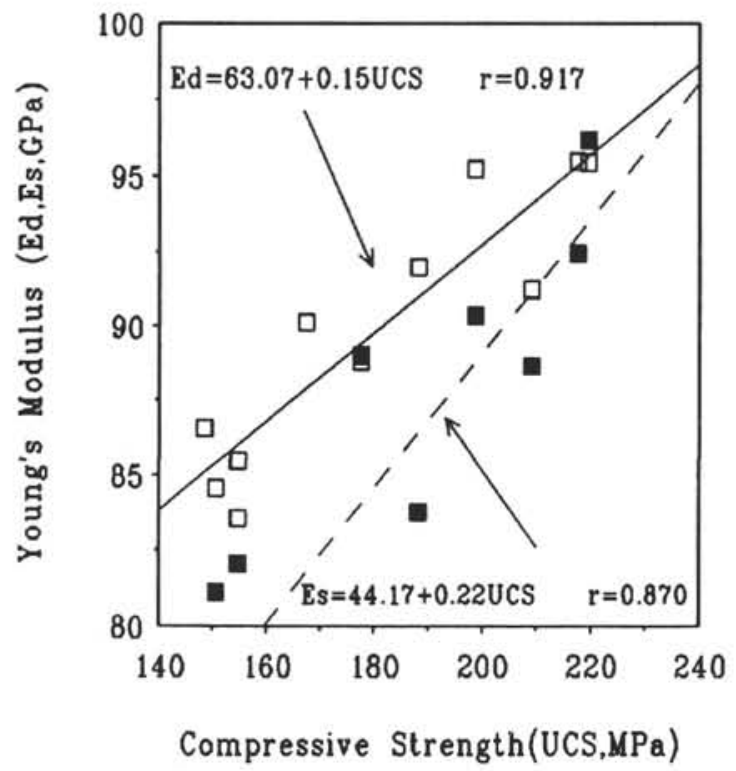

Figure 6. Correlation diagram between uniaxial compressive strength (UCS) and dynamic/static Young's moduli $\left(E_{d}, E_{s}\right)$ of basalts from Hole 504B, Leg 137. Open squares $=E_{d}$; filled squares $=E_{s}$.

the rock fabric, considering that ultrasonic velocity is directly related to the density and the general form of the rock. The relatively low correlation coefficients $r=-0.605$ and $r=0.586$ in Figure 3 are due to the points " $5.828,1.19$ " and " $5.609,56.88$ " corresponding to AR and $\mathrm{H}$ measurements, respectively, although the above correlation coefficients are high enough at the level of $98 \%$.

Uniaxial compressive strength is related to the ultrasonic velocity, Young's modulus, dry-bulk density, and hardness (Figs. 5, 6, 7, and 8). The points "198.7, 1.19" and "150.6, 56.88" in Figure 8, corresponding to the same points of Figure 3, lower the correlation significance between compressive strength and hardness. Test values do not differ significantly from those given by Bauer and Handin (1985) for more shallow depths in the same hole during Leg 83 .

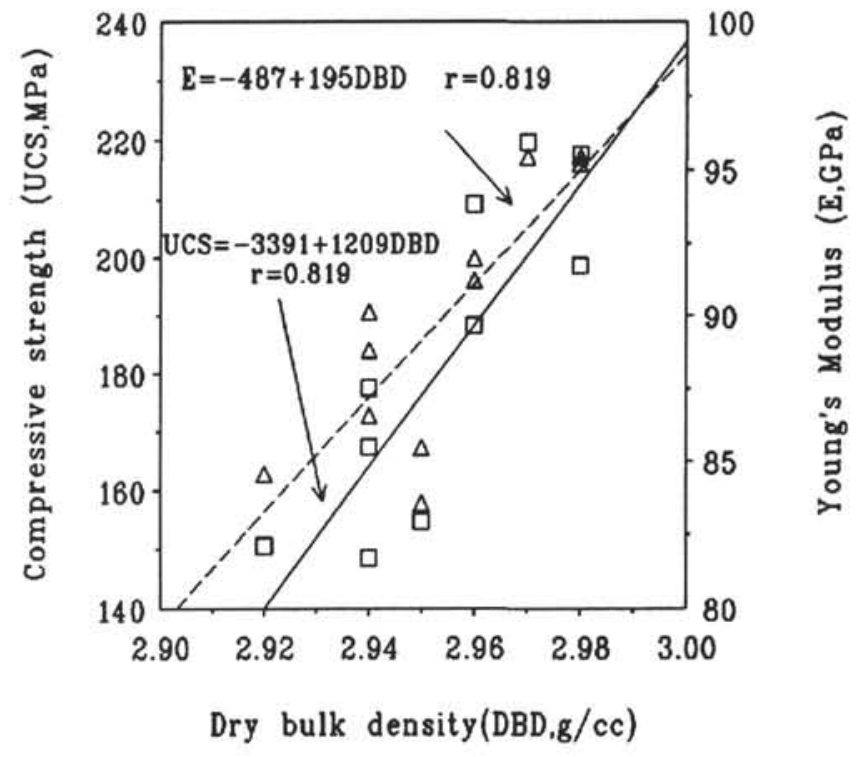

Figure 7. Correlation diagram between dry-bulk density (DBD) and uniaxial compressive strength (UCS) as well as Young's modulus $(E)$ of basalts from Hole 504B, Leg 137. Squares $=$ UCS; triangles $=E$.

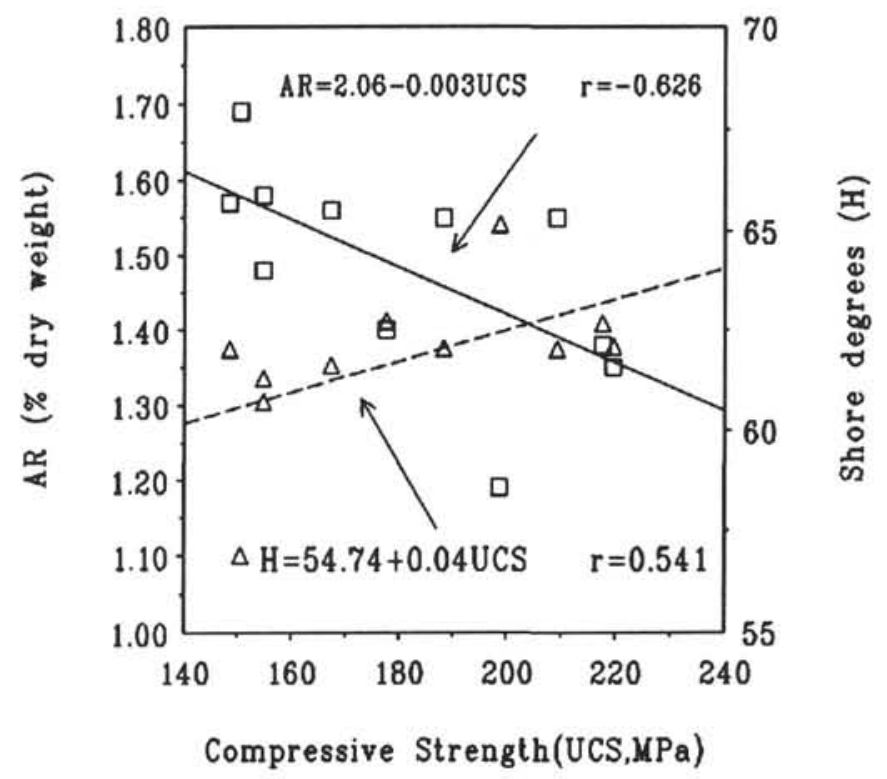

Figure 8. Correlation diagram between uniaxial compressive strength (UCS) and hardness $(\mathrm{AR}, \mathrm{H})$ of basalts from Hole 504B, Leg 137. Squares = AR; triangles $=\mathrm{H}$.

Static Young's modulus is related linearly to the dynamic one (Fig. 9). Data from the static method are generally lower than those from the dynamic one. The regression determined does not differ significantly from the following regression, given for several superficial rocks of France (including basalt), according to Christaras et al. (in press):

$$
\begin{gathered}
E_{s}=-3.16+1.05 E_{d} \\
r=0.994
\end{gathered}
$$

One important problem is that all tests were made using dry specimens, in Earth surface pressure and temperature conditions. The in-situ conditions are quite different because the material is saturated, 


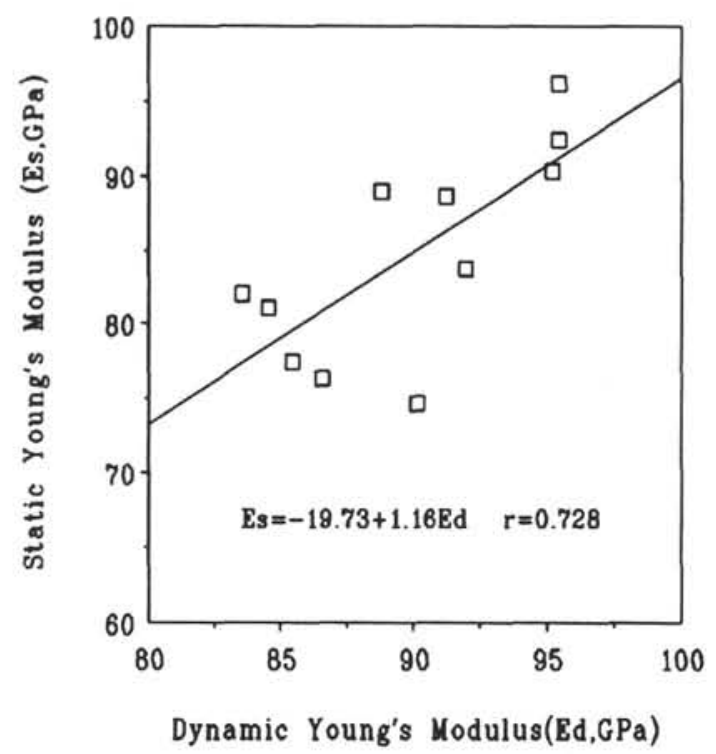

Figure 9. Correlation diagram between dynamic $\left(E_{d}\right)$ and static $\left(E_{s}\right)$ Young's moduli of basalts from Hole 504B, Leg 137.

the temperature is higher than $100^{\circ}$, and the pressure is about $500 \mathrm{~atm}$ or higher. So, test results in surface conditions can differ from the in-situ measurements. In our tests, the material used was derived from cores taken without conserving the in-situ pressure conditions, so many cracks were probably created after coring operations. In this case, the use of in-situ pressure conditions in the laboratory can be dangerous for the accuracy of the results. Furthermore, wet specimens, in surface conditions, do not represent the mechanical behavior of the material better than the dry specimens.

\section{CONCLUSIONS}

In the present investigation, 11 samples of basalt from Hole 504B were studied regarding their hardness, uniaxial compressive strength, and coefficient of elasticity. Test values were similar to those of a fresh basalt, remaining more or less constant with the depth. The significant relationships that these properties present make test results worthy of credit and comparable. Abrasion hardness values compared with those of the commonly used Shore method provided a high-significance correlation, confirming the precision of the method. Young's modulus was measured using both static and dynamic methods. Test results of these two methods are comparable to each other.

\section{REFERENCES}

Alt, J.C., Honnorez, J., Laverne, C., and Emmermann, R., 1986. Hydrothermal alteration of a $1 \mathrm{~km}$ section through the upper oceanic crust, Deep Sea Drilling Project Hole 504B: mineralogy, chemistry, and evolution of seawater-basalt interactions. J. Geophys. Res., 91:10309-10335.

Bauer, S.J., and Handin, J., 1985. Mechanical properties of basalt cores from Deep Sea Drilling Project Hole 504B. In Anderson, R.N., Honnorez, J., Becker, K., et al., Init. Repts. DSDP, 83: Washington (U.S. Govt. Printing Office), 371-375.

Christaras, B., 1991a. Old stone bridges in Epirus/Greece. 2nd Int. Congr. Conserv. Monum. Medit. Basin, Geneve.

1991b. Méthode d'évaluation de l'altération et modification des propriétés mécaniques des granites en Grèce du Nord. Bull. IAEG, 43:21-26.

- in press. Hardness test using a thin section lapping machine: application on ophiolitic specimens from Chalkidiki/Greece. Proc. Int. Congr, Geol. Soc. Greece, Athens.

Christaras, B., Auger, F., and Mosse, E., in press. Determination of the Elastic Moduli of rocks: comparison of the ultrasonic velocity and mechanical resonance frequency methods to the direct static one. Mater. Constr. Paris.

Clark, G.B., 1966. Deformation moduli of rocks. ASTM Spec. Tech. Publ., 402:133-174

Dearman, W.R., 1976. Weathering classification in the characterization of rocks: a revision. Bull. IAEG, 13:123-127.

Jaeger, J.C., and Cook, N.G.W., 1979. Fundamentals of Rock Mechanics (3rd ed.): New York (Chapman and Hall).

Johnson, R.B., and De Graff, J.V., 1988. Principles of Engineering Geology: New York (Wiley).

Morin, R.H., Anderson, R.N., and Barton, C.A., 1989. Analysis and interpretation of the borehole televiewer log: information on the state of stress and the lithostratigraphy at Hole 504B. In Becker, K., Sakai, H., et al., Proc. ODP, Sci. Results, 111: College Station, TX (Ocean Drilling Program), $109-118$.

Shipboard Scientific Party, 1992. Site 504. In Becker, K., Foss, G., et al., Proc. ODP, Init. Repts., 137: College Station, TX (Ocean Drilling Program), $15-55$.

Tsoutrelis, T.C., 1968. An investigation on the effects of the physical properties of rocks on the speed of penetration by diamond drilling. Geol. Geogr. Res., $1: 259$.

\footnotetext{
-Abbreviations for names of organizations and publications in ODP reference lists follow the style given in Chemical Abstracts Service Source Index (published by American Chemical Society).
}

Date of initial receipt: 22 March 1993

Date of acceptance: 13 August 1993

Ms 137/140SR-033 